\title{
Globalization and firm's quality orientation: a review of total quality management practices in manufacturing sector
}

\author{
aHayat, M. Awan, bM. Ishaq Bhatti and cKhuram Shahzad Bukhari \\ ac Institute of Management Sciences, Bahauddin Zakariya University, \\ Multan Pakistan \\ b La trobe University, Melbourne \\ Australia
}

\section{Introduction}

Most of the developed Countries have progressed during the past couple of decades through internationalization of their products and services. Pakistan like other developing economies is also trying hard to exploit business opportunities in international markets and has succeeded as far as textile and sport ware are concerned. Pakistani Sports Industry, though always relying on high quality products, lacked a formal quality management programme till 1990's. It was during this decade that most of sports industries adopted a formal quality management programme in the shape of ISO-9000.

The Johanson and Vahlne model sees internationalization as a process in which the enterprise gradually increases its international involvement. This process evolves in interplay between the development of knowledge about foreign markets and operations on one hand and an increasing commitment of resources to foreign markets on the other but the question arises how? What makes a product sell? What are the prime requisites for internationalization?

The factors determining sale success and successful internationalization process are many and varied. They include market conditions (Dale, 1996), the nature of the product, the image created by advertising, the socio-cultural background of customers (Martinez and Rodriguez; 1997), credit facilities and many more. One major factor that appears in all conditions is "Product Quality" as perceived by the customer. It can be argued that powerful media campaigns can create demand for anything. This may be possible as far as the initial launch of the product or the first sale is concerned. However repeat and sustained sales can be achieved only on the basis of good quality at a reasonable price. A business concern could fail despite producing good quality products, but with poor quality no enterprise can sustain itself for long particularly when it comes to globalization. 
Quality - as broadly applies to products, process, people, and environment - and its control has become increasingly important in today's competitive global market place. Consumers whether it is local ore global, expect quality in the products they buy and exert great pressure on producers to maintain high standard of quality. Likewise producers rely more on international distribution networks and realize that if they are not competitive in all aspects of quality, they would find it very difficult to survive even what the question to compete. With the emergence of New World Trade Order and initiation of 21st Century, there has been dramatic change in trends, practices and outlook of the business environment in all around the world. Standards play an increasingly important role in the development of the "global village". Market globalization has fostered an important and positive move toward the internationalization of standards. Countries that have introduced and adopted standardized policies have gained an advantage over countries that have been slower to adoption process.

ISO standards are organized in such a way as to guarantee the involvement of all parties involved. A distinctive feature of quality assurance is that it transfers verification of requisites from the product to the system that produces the product. ISO-9000 series provides the basis for the third party certification of a company's quality system by establishing the standard that must be met. Under these, standards control exists for every aspect of production process. Achieving ISO-900 registration requires third party assessment and periodic audit of the quality system to confirm that the system meets and adheres to ISO-9000 standard and this ISO registration increases the acceptance of the products globally. There are established empirical evidence to justify linkage between a firm's quality orientation and business performance. A better quality orientation enables firm to reduce costs, improve customer loyalty, and to attract new customers; which influence overall performance of the firm in a positive manner. When it comes to the question of sustaining the performance improvement on continuous basis quality orientation reflects its positive contribution in the form increased return on investment (ROI), profits, sales volume, market share and sales growth (Jackson 1998).

While being in international markets, these advantages are being eroded by the considerable downward pressure on prices, by difficulties in logistic planning and control, and by inadequate information system especially when it comes to developing countries like Pakistan, where economic dependence is mainly on exports, quality management practices become even more critical for competitive positioning of firms in international market. If organizations will not choose to develop better quality orientation and adopt quality oriented management practices, they won't be able to position themselves in international markets. Despite of its critical importance, there is lack of consensus among most of the firm in manufacturing sector about standards and means to develop quality orientation or there is lack of sufficient knowledge (Hayat et al 2009). Findings of these studies suggest that determinants of quality orientation of the firms are not relevant in generic sense to all organizations and quality management is long term process which relies on relative achievement through continuous improvement. Total Quality Management practices help in exploiting opportunities for developing economic conditions of a country and also helps in reaching global markets (Riyad Eid; 2009, Mora Mong et al; 2008 ) 
Lipovatz et al (1999) [ibid, Berry (1998), Tummala (1998), Tang (1998), Tsiotras and Gotzamani (1998)], state that now-a-days for a company to receive ISO-9000 approval is not only a fashion or trend but also a general requirement toward what is needed to run a good business. At the beginning, many companies perceived the certification as a tool for improving their market position. As the number of certificates continuously increases, the certification tends to become rather a prerequisite for company's survival than a competitive advantage. Although different opinions are often expressed, many researchers consider the existence of quality assurance standard (QAS) to be an essential first step towards the adoption of total Quality Management, which aims at the continuous improvement of business performance with principal focus on the customer's satisfaction and the gain of a competitive advantage (Awan, 2002). Total quality Management and ISO-9000 has a strong relationship with each other. Both are used to improve the quality of the product and service. The concepts of quality management have been widely accepted and adopted since the Second World War (Lee et al 1999). Since the publication of ISO-9000 series of standards in 1987, they are used by many companies and organizations as an important milestone to mark their quality journey. In particular, many buyers and merchandisers in the national and international markets use ISO-9000 certification as a primary criterion in their selection of suppliers. ISO-9000 quality management system is the most widely recognized quality model for the purpose of certification. The route to TQM is definitely not an easy one, however many organizations striving to attain TQM have chosen ISO-9000 certification as a stepping stone to achieving this goal (Quazi et al 1977).

In summary, the crucial importance of developing quality orientation for smooth and sustainable transition to international market, the lack of theory and research in developing context indicates need for a conceptual framework of quality orientation within the context of developing economy like Pakistan. This will give a roadmap to other organizations in developing countries to develop a quality orientation that can facilitate a sustainable growth and expansion towards international markets. In this study an attempt has been made to define how quality orientation of the firm can be defined within the context of a developing economy by analyzing the quality management practices of manufacturing sector in Pakistan.

The main thirst of this study is to identify determinants of quality orientation for manufacturing industry of Pakistan and to understand how different organizations are addressing these issues. Major areas of interest in this study would be to explore and analyze literature in order to develop better understanding of market specific and quality specific factors and the way these factors complement each other for providing the firm a sustainable foundation for international expansion.

Secondly, this study identify of key practices of TQM in selected manufacturing industries like Textile, Sports, Electronics, Automobiles and others to develop conceptual framework for firm's quality orientation. Proposed framework of firm's quality orientation comprises of three tiers, each tier contains a set of factor with respect to their level of importance for developing effective quality orientation. Jackson, M. I (1998) proposed similar set of factors for firm's quality orientation by using exploratory research method, there is a substantial gap since then in further development and validation of quality orientation factors and empirical evidence for quality orientation construct is missing. This study attempts to fill 
this gap by empirically validating the significance of each factor that can be used for describing the construct of firm's quality orientation. This study uses comprehensive criticality index (CC index) based on the importance of the criticality of these factors and to classify these indices in descending order in three tiers. The relationship among these three tiers of critical quality orientation factors and business performance is investigated. In order to study the variation in relationship between quality orientation factors and firm's performance among four types of industries, following differentiating factors are used: manufacturing style, management practices and working. The results of this study will be useful for managers of individual industry and they may think for the adaptation of these practices, for successful transition to the international market. Rest of the paper is organized as follows. Section 2 gives the literature review and an overview of previous studies. Section 3 presents the process of data collection and research methodology. This will Followed by statistical procedures, the results and conclusions.

\section{Literature Review}

Internationalization and quality management are inextricably intertwined. And quality management is considered to be the prime requisite for internationalization (Abdi et al 2008). The term globalization and internationalization are to be seen as distinct but linked concepts (Gnanam, A. 2008). In the wake of globalizing economy, individual countries are left with no option but to facilitate outward movement of the international operations of a firm that is referred as process of 'internationalization' (Welch and Luostarinen.; 1993; Andersen, O., 1993). This engagement involves the process of adapting the firm's operations to cope with the strategy, structure and resources of international environments

Whenever firm engages itself in international business activity, needs to position their offerings on competitive standards of quality. However, achievement of competitive standards of quality with particular reference to international market is not a simple management strategy, rather an evolutionary process of organizational development. Dale (1994) identified four stages of this progression of quality namely: inspection, quality control, quality assurance and total quality management. First two stages i.e. quality inspection and quality control provide the organization opportunity to gradually start quality improvement process from detection of variation from standards. Quality standards at this stage of quality improvement program of the firm can be considered as set of standard operating procedures (SOPs) which provide basis for conformance to the specifications of quality standards. Geneva based international standards organization (ISO) introduced ISO-9000 series in 1987, which provide guidelines about requirements and suggest appropriate assessment procedures for the improvement of management system of the firm at par with the internationally acceptable set of standards for manufacturing and service industries (Alexander, 1995). It is maintained by ISO, the International Organization for Standardization and is administered by accreditation and certification bodies. The rules are updated, as the requirements motivate changes over time. It is reshaping the core value of business practices. Firms that have introduced standardization policies have gained an advantage over the firms that have been slower to move. A "product", in ISO vocabulary, can mean a physical object, services, or software. "Quality" is an important accreditation to achieve. The route to TQM is definitely not an easy one, however many organizations 
successfully implemented TQM, opted for ISO-9000 certification as stepping stone for the achievement of this goal (Quazi et al 1997; Baidoun, 2004; Terziovski and Power, 2007).

Internationalization is also conceived as gradual process which has the long term orientation. The Johanson and Vahlne model sees internationalization as a process in which the enterprise gradually increases its international involvement. This process evolves in interplay between the development of knowledge about foreign markets and operations on one hand and an increasing commitment of resources to foreign markets on the other. The best developed interpretation of the internationalization of smaller firms is presented by Johanson and Wiedersheim - Paul (1975) and Johanson and Vahlne (1977). In their internationalization model, the process approximates a learning curve on a number of patterns can be discerned. The sequences of "Stages" also indicate increased commitment of resources to the market as a result of greater knowledge and experience. Secondly, that firm initially focuses on neighboring countries and subsequently enters new markets with successively greater Psychic distance in terms of cultural, economic and political differences and also of geographical proximity.

Various stages of an organization's pattern of development associated with growth generally and its ability to learn and adapt to new situations, thus changing its character are, of course, important determinants in respect of the internationalization process. Siropolis proposes a simple four staged linear pattern of growth in terms of the generic development of a business: "Pre-birth", "Acceptance" (Infancy), "breakthrough" (growing up) and maturity that's adulthood stage (Siropolis 1994). Such a model is useful in considering the manner in which equivalent stages of "internationalization" progress and the implications that are associated with each phase. For organizations in early stages of internationalization, the early phases of "infancy" and growing up" are critical learning periods, as in the development of a child, where key occurrences can shape personality and affect subsequent progression. These are also some important periods during the phase of internationalization of the business. The embryonic "Pre-birth" phase must not be ignored in respect to its influence upon subsequent stages in the evolutionary process. It is at this phase of internationalization that the management and organizational learning needs foundation is to be laid. Quality improvement is also the gradual process companies in short run go for 1SO 9000 which pave their way for the adoption of total quality management in the long run. Many small firms have competitive product or services but do not exports they have increasingly became the main target of government export simulation programs. Realization of maximum benefits of TQM practices essentially require complete knowledge of critical quality factors which are now days considered to be the Competitive strategies that are designed to extend a value gap, and make it difficult for the competitors to imitate. In a number of studies researchers praise openly TQM, others have also come up with the criticism by taking cost and implementation obstacles as base. Quality is the key to competitive advantage in today's business environment. As more organizations opt for Total Quality Management (TQM), the choices open to those wanting to set up a quality system are becoming increasingly varied. 
Johanson and

Wiedersheim-Paul (1975)

Bilkey and Tesar (1977)

Cavusgil (1980)

Czinkota (1982)

\begin{tabular}{|c|c|c|c|}
\hline & \multirow[b]{2}{*}{$\begin{array}{l}\text { Stage } 1 \\
\text { Management is not } \\
\text { interested in } \\
\text { exporting }\end{array}$} & \multirow[b]{2}{*}{$\begin{array}{l}\text { Stage } 1 \\
\text { Domestic marketing } \\
\text { the firm sells only to } \\
\text { the home market }\end{array}$} & \multirow[b]{2}{*}{$\begin{array}{l}\text { Stage } 1 \\
\text { The completely } \\
\text { uninterested } \\
\text { firm }\end{array}$} \\
\hline & & & \\
\hline $\begin{array}{l}\text { Stage } 1 \\
\text { No regular } \\
\text { export } \\
\text { activities }\end{array}$ & $\begin{array}{l}\text { Stage } 2 \\
\text { Management is } \\
\text { willing to fill } \\
\text { unsolicited orders, } \\
\text { but makes no effort } \\
\text { to explore the } \\
\text { feasibility of active } \\
\text { exporting }\end{array}$ & $\begin{array}{l}\text { Stage } 2 \\
\text { Pre-export stage: the } \\
\text { Firm searches for } \\
\text { information and } \\
\text { evaluates the } \\
\text { feasibility of } \\
\text { undertaking } \\
\text { exporting }\end{array}$ & $\begin{array}{l}\text { Stage } 2 \\
\text { The partially } \\
\text { interested firm }\end{array}$ \\
\hline \multirow[t]{2}{*}{$\begin{array}{l}\text { Stage } 2 \\
\text { Export via } \\
\text { overseas } \\
\text { agents }\end{array}$} & $\begin{array}{l}\text { Stage } 3 \\
\text { Management } \\
\text { actively explores } \\
\text { feasibility of active } \\
\text { exporting }\end{array}$ & $\begin{array}{l}\text { Stage } 3 \\
\text { Experimental } \\
\text { involvement the firm } \\
\text { starts exporting on a } \\
\text { limited basis to some } \\
\text { psychologically close } \\
\text { countries }\end{array}$ & $\begin{array}{l}\text { Stage } 3 \\
\text { The exploring } \\
\text { firm }\end{array}$ \\
\hline & $\begin{array}{l}\text { Stage } 4 \\
\text { The firm exports on } \\
\text { an experimental } \\
\text { basis to some } \\
\text { psychologically } \\
\text { close country }\end{array}$ & $\begin{array}{l}\text { Stage } 4 \\
\text { Active involvement: } \\
\text { Exporting to more } \\
\text { new countries - } \\
\text { direct exporting - } \\
\text { increase in export } \\
\text { volume. }\end{array}$ & $\begin{array}{l}\text { Stage } 4 \\
\text { The } \\
\text { experimental } \\
\text { Exporter }\end{array}$ \\
\hline \multirow{2}{*}{$\begin{array}{l}\text { Stage-3 } \\
\text { Establishment } \\
\text { of an overseas } \\
\text { sales } \\
\text { subsidiary }\end{array}$} & $\begin{array}{l}\text { Stage } 5 \\
\text { The firm is an } \\
\text { Experienced } \\
\text { exporter }\end{array}$ & \multirow{3}{*}{$\begin{array}{l}\text { Stage } 5 \\
\text { Committed } \\
\text { involvement } \\
\text { management } \\
\text { constantly makes } \\
\text { choices in allocating } \\
\text { limited resources } \\
\text { between domestic } \\
\text { and foreign markets }\end{array}$} & $\begin{array}{l}\text { Stage } 5 \\
\text { The experienced } \\
\text { Small exporter }\end{array}$ \\
\hline & $\begin{array}{l}\text { Stage }-6 \\
\text { Management } \\
\text { explores the } \\
\text { feasibility of } \\
\text { exporting to other } \\
\text { more } \\
\text { psychologically } \\
\text { distant country }\end{array}$ & & $\begin{array}{l}\text { Stage-6 } \\
\text { The experienced } \\
\text { large exporter }\end{array}$ \\
\hline $\begin{array}{l}\text { Stage-4 } \\
\text { Overseas } \\
\text { Production } \\
\text { Manufacturing }\end{array}$ & & & \\
\hline
\end{tabular}

Fig. 1. Summary of Four Export Development/ Internationalization "Stage" Models (Source: Research Developments in International Marketing: A European Perspective, ford and Leonidu, 1991)

Prior to mid 1970's international business activity was considered to be the prerogative of large corporations and global markets were regarded as the domain of multinational 
enterprises (MNE's). Most Governments relied extensively on large indigenous or foreignowned business to provide the engine for economic development and trade growth. Smaller firms received scant attention from policy-makers and researchers alike. It was widely assumed that due to backward technologies, inadequate management and inferior organization - they would play an increasingly residual role in advancement of economies. These perceptions began to change in the 1970's. Worldwide recession in the aftermath of the 1973-74 "Oil Crises" led to sluggish demand in saturated domestic markets and to a slump in world trade. Intense global competitions emanating from Japan and the newly industrialized natives aggravated the balance of trade deficits of many advanced economies and provoked severe foreign - debt problems among lesser developed countries. Then since mid-1970's, small firm internationalization has become an important research topic, not only within small open economies - notably, Scandinavian nations, which due to small - firm bases and limited domestic markets, have been in the vanguard of such enquiry. (Johanson and Wiedersheim - Paul, 1975), but also in sizeable economies where the export activities of small firms are not as critical, yet still offer significant incremental contributions to foreign trade (Bilkey and Tesar 1977, Joynt, 1982). Moreover, issues relating to small firm exporting and internationalization have generated considerable policy maker interest worldwide, not just in terms of the potential macro-economic benefits to be derived firm the trade growth, but also because - in an increasingly global market place export operations often offer individual firms an attractive alternative strategy for survival and growth (WiedersheimPaul et al 1978, Reid 1981, Kaynak and Kothari 1984). Thus as many smaller firms have competitive product or services offerings but do not export they have - increasingly became the main targets of government export stimulation programmes.

\section{Quality management Orientation \& Internationalization; Case of Sports Industry of Pakistan}

We will assess the importance of quality management in the process of internationalization in sports industry of Pakistan. The sports goods industry is one of the largest small-scale manufacturing set up in Sialkot, Pakistan. Sialkot is the soccer ball capital of the world. At its height in the mid-1990s, nearly $80 \%$ of the world's soccer balls were stamped with "made in Pakistan" and were, in fact, made in Sialkot. All of the major brands had operations in Sialkot including Nike, Adidas and Puma. Up until that time, the industry functioned as a cottage industry. The sports goods being manufactured for export from Sialkot include Tennis ball \& rackets, hockey sticks and balls, polo sticks, cricket bat \& balls, foot balls, badminton rackets etc. The industry is one of the major foreign exchange earners for Pakistan and is therefore receiving full Government backing in its development. It is expected that more than $75 \%$ of the total production is exported every year. In fact the export demand has acted as the main stimulus for the rapid growth of this industry. At the time of independence, this industry was in an infant age with a nominal export of Rs.0.82 million. The Government took immediate steps to develop this industry by providing loans and subsidies to the manufacturers and arrangement were made to market the manufactured goods. Since then the industry has flourished locally and enjoys good reputation in international markets as well. Export of sports goods increased from $\$ 141$ million in 1991-92 to \$ 248 million in 1995-96; Showing an average increase of $15 \%$ per annum (Awan, 2003). 
This increase in exports revenue is attributed to the adoption of formal Quality Programme in the form of ISO-9000. Industry in particular holds a monopolistic position in world trade with almost $70 \%$ share. Pakistan Football is played in all international matches and tournaments. International companies like Adidas, Puma, Select, Nike, Mitre and Reebok buy their major share of footballs and football goal keeper gloves from Pakistan. Pakistan Martial Art uniforms and Boxing equipment are considered the best all over the world. Japan, USA and EU, countries are the major buyers. Hockey sticks too are sold like hot cakes.

Pakistan's sports goods industry has progressed with prominence and achieved recognition at the global level. Presently, approximately 250 sports items are manufactured and exported to more than 130 countries of the world. Sialkot being the nucleus of this industry, has achieved an excellent craftsmanship. This is reflected in its sports items with recognition all over the world in spite of having inadequate technology and supply of raw material. Thousands of skilled craftsmen are working in hundreds of big and small factories in the city of Sialkot as well as in the suburban villages of this city. An employment of about 300,000 people directly or indirectly is associated with this sector. The total value of exports of sports goods at the international level is approximately US\$25 billion till the year 2006, which comprises more than 10,000 sports items (K. Bukhari, 2006).

This industry has kept pace with all innovation in the manufacturing technology. The hockey industry has a remarkable distinction of being marketed in the world with its own brand names which is by no means a small achievement. India China, Japan, Taiwan and South Korea are competing with Pakistan in international markets by supplying their products at cheaper rates. India \& China have an advent of cheap labour and raw material, whereas others have semi automatic mechanized units and are always engaged in introducing cheap sports gears such as metal racket and cricket bats etc. Pakistan sports goods industries have progressed from cottage industry scale to semi-automotive level by modernization and introducing new technologies. The industry should now increase the bulk of its production and enlarge its area of export. The level of internationalization should therefore be enhanced which can only be achieved through producing high quality products consistently and this can only be achieved through adoption of proper Quality control Systems. For the internationalization of products the image of the country also plays an important role to create acceptance of product globally. In the absence of such reinforcing country image the importance of the quality of the products becomes even more important as is the case with Pakistan.

These are so many factors which influence the internationalization of a firm. In their paper in the international marketing Review (1989) titled "Management influences on export performance: A review of the Empirical Literature 1978-87, Nils Erik Aaby et al organized the management influences in three areas namely

1. $\quad$ Firm Characteristics
2. $\quad$ Competences
3.

Firm characteristics are sub-divided into three categories, these include variables related to firm size, management export commitment and management attitudes and perceptions on a number of important export related dimensions. Organization size has received varied attention. The most common hypothesis is that the larger companies have size-related 
advantages that enable them to more effectively engage in export. Reid (1982) says that size affects export entry into new foreign markets. Cavusgil and Nevin (1981) Christensen et al (1987) and Gronhaug \& Lorenzen (1982) find size related differences between exporters and non-exporters. In contrast Cooper and Kleinshmdit (1985) establish a negative relationship between size and export intensity. While McGuinness and little (1981), Czinkota and Johanston (1983) and Diamantopoulos and Inglis (1988) conclude no relationship.

Management commitment and propensity to export has received a unanimous positive relationship (Bello and Barksdale 1986; Cavusgil 1984; Cavusgil et al 1979 Gronhaug and Lorenzen 1982, Kirpalani \& Macintosh 1980, Rosson \& Ford 1982, and Sullivan and Bauershmidth 1987). Similarly many studies evaluated relationships among management perceptions, attitudes and the propensity to export. Under the heading "Competencies", different variables namely technology, export policy, planning, market knowledge management systems, quality control \& communication capability have been grouped together.

Burton and Schlegelmilch (1987) and Christensen et al (1987) found that successful exporters had a stronger quality control function. Departments were better organized and department managers were better qualified than in firms that had abandoned their export programmes. Daniels and Robles (1982) concluded that product quality was a key competency for Peruvian exporters. Joynt (1982) reported that Norwegian exporters perceive their most important competency to be product quality. In contrast, Malek Zadeh and Nahavandi (1985) concluded that research in this area is limited and the results are unclear.

The third variable important in internationalization is "strategy". Market selection, product, product line \& processes, prices, promotion and distribution constitute the "strategy" part of the management influences on export performance. Intense global competition has forced many firms to examine their care business processes and to devise plans to respond to an increasingly competitive market place. Underlying responses to global competition has been the recognition of the role of product and process improvement in business strategy, throughout the 1990's firms examined and in many cases, changed their quality focus. Instead of relying on inspecting quality into products, they emphasized improving processes. Total quality management became a major element in corporate strategy. Significant numbers of firms adopted quality programs during the 1990's. Quality improvement is but one way for an organization to improve its competitiveness. Even in the absence of competition, improvements in quality can facilitate an organization's competitiveness; though as witness over the last decade, competition has for many organizations been the driver of quality improvement efforts.

\section{Research methodology}

The research reported in this paper is based on case studies of six firms operating in sports industry in Pakistan. In depth interviews were conducted at each firm to find out quality management practices and their impact on the level of internationalization. These firms are characterized as L (Large), M (Medium) and S (Small).

A structured questionnaire is developed by considering observations from literature survey with emphasis on finding out the impact of quality management on the process of internationalization. Sports companies operating in Sialkot (Pakistan) were taken as Population. Cluster sampling technique was applied and under cluster sampling "Random Sampling" method was used. Size of the sample was 100 sports companies, out of which 89, provided useable responses. 


\section{Observations}

\section{Case Studies}

This portion presents an analysis of case study of six firms operating in sports industry. In depth site interview were conducted at each firm to obtain detailed information about the TQM implementation, benefits, difficulties and especially with reference to its impact on the export performance of these firms. These firms include Talon Sports, SAGA Sports and Awan Sports, Anwar Khawaja Industries (AKI), Fox \& Associates \& A.M. Sports. Categorization of these firms is done as large, medium and small on the basis of turnover. Those having an annual turnover of more than Rs.500 million are categorized as large, above Rs.100 million but less than 500 million as medium and below Rs.100 million as small. Anwar Khawaja Industries has another hall mark that it is a sister concern of Grays of Cambridge, a joint venture of AKI \& Grays. No. of Employees beyond 1000 was considered as large, between 100-1000 considered as medium \& below 100 was categorized as small.

The structured portion of the interview utilized a questionnaire that was based on a comprehensive review of literature. Also this study presents the results of personal observation, and company publications. The details of these cases have been presented in Abdi, (2005). The general information about these firms are presented in the

\begin{tabular}{|l|l|l|l|l|l|l|l|}
\hline rr.No. & Description & $\begin{array}{l}\text { Talon } \\
\text { Sports }\end{array}$ & $\begin{array}{l}\text { Saga } \\
\text { Sports }\end{array}$ & $\begin{array}{l}\text { Anwar } \\
\text { Khawaja }\end{array}$ & $\begin{array}{l}\text { Awan } \\
\text { Sports }\end{array}$ & $\begin{array}{l}\text { Fox } \\
\text { Associates }\end{array}$ & A.M. Sports \\
\hline 01. & $\begin{array}{l}\text { Size of } \\
\text { Company }\end{array}$ & Large & Large & Medium & Medium & Small & Small \\
\hline 02. & $\begin{array}{l}\text { Scope of } \\
\text { Business }\end{array}$ & Exports & Exports & Exports & Exports & Exports & $\begin{array}{l}\text { Domestic \& } \\
\text { Export }\end{array}$ \\
\hline 03. & $\begin{array}{l}\text { Nature of } \\
\text { Company }\end{array}$ & $\begin{array}{l}\text { Private } \\
\text { Ltd., }\end{array}$ & $\begin{array}{l}\text { Private } \\
\text { Ltd., }\end{array}$ & $\begin{array}{l}\text { Private } \\
\text { Ltd., }\end{array}$ & $\begin{array}{l}\text { Private } \\
\text { Ltd., }\end{array}$ & Partnership & Proprietorship \\
\hline 04. & $\begin{array}{l}\text { No. of } \\
\text { Employees }\end{array}$ & 1265 & 1200 & 317 & 355 & 77 & 10 \\
\hline 05. & $\begin{array}{l}\text { Turnover, Rs. } \\
\text { Million }\end{array}$ & 800 & 1400 & 371 & 160 & 0 & 05 \\
\hline 06. & $\begin{array}{l}\text { Experience in } \\
\text { Exports } \\
\text { (Years) }\end{array}$ & 10 & 20 & Over 20 & 20 & 10 & Below 10 \\
\hline
\end{tabular}

Table 1. Company Background Information

The cases under study are export oriented, they have implemented TQM and also they are ISO certified except one. They first got ISO registration and based on that implemented TQM. Personal observations and essence of interviews is summarized as under; 


\begin{tabular}{|c|c|c|c|c|c|c|c|}
\hline $\begin{array}{l}\text { Sr. } \\
\#\end{array}$ & Description & \begin{tabular}{|l} 
Talon \\
Sports \\
(Pvt) Ltd.
\end{tabular} & $\begin{array}{l}\text { Saga Sports } \\
\text { (Pvt) Ltd. }\end{array}$ & $\begin{array}{l}\text { Anwar } \\
\text { Khawaja }\end{array}$ & \begin{tabular}{|l} 
Awan \\
Sports \\
(Pvt) Ltd.,
\end{tabular} & \begin{tabular}{|l} 
Fox \\
Associate \\
s.
\end{tabular} & $\begin{array}{l}\text { A.M. } \\
\text { Sports }\end{array}$ \\
\hline 01 & ISO Certification & Yes & Yes & Yes & Yes & Yes & No \\
\hline 02 & \begin{tabular}{|l} 
Management \\
Commitment to \\
Quality
\end{tabular} & Yes & Yes & Yes & Yes & Yes & Yes \\
\hline 03 & $\begin{array}{l}\text { Years in Quality } \\
\text { Management }\end{array}$ & 05 & 13 & 04 & 03 & 04 & Nil \\
\hline 04 & $\begin{array}{l}\text { Suppliers to be ISO } \\
\text { certified }\end{array}$ & Preferred & Preferred & Preferred & Preferred & Preferred & No \\
\hline 05 & $\begin{array}{l}\text { Customer Pressure } \\
\text { for ISO Registration }\end{array}$ & No & No & Yes & Yes & Yes & Yes \\
\hline 06 & $\begin{array}{l}\text { \%age of Employees } \\
\text { Received Quality } \\
\text { Training }\end{array}$ & $100 \%$ & $100 \%$ & $100 \%$ & $100 \%$ & $100 \%$ & Nil \\
\hline 07 & TQM in Practice & Yes & Yes & Yes & \begin{tabular}{|l|} 
Efforts \\
underway
\end{tabular} & Yes & No \\
\hline 08 & $\begin{array}{l}\text { Statistical } \\
\text { Techniques used }\end{array}$ & Yes & Yes & Yes & Yes & Yes & No \\
\hline 09 & $\begin{array}{l}\text { Reject rate before \& } \\
\text { after ISO }\end{array}$ & $9 \%$ to $4 \%$ & $10 \%$ to $4 \%$ & $10 \%$ to $5 \%$ & $15 \%$ to $5 \%$ & $15 \%$ to $3 \%$ & Not Known \\
\hline 10 & $\begin{array}{l}\text { Impact of quality } \\
\text { management on } \\
\text { sales }\end{array}$ & Increased & Increased & Increased & Increased & Increased & Not Known \\
\hline 11 & $\begin{array}{l}\text { Frequency of } \\
\text { exports after } \\
\text { quality } \\
\text { management }\end{array}$ & Increased & Increased & Increased & Increased & Increased & Not Known \\
\hline 12 & $\begin{array}{l}\text { Stage of } \\
\text { Internationalization }\end{array}$ & $\begin{array}{l}\text { Experienc } \\
\text { ed large } \\
\text { exporter }\end{array}$ & $\begin{array}{l}\text { Experienced } \\
\text { large } \\
\text { exporter }\end{array}$ & $\begin{array}{l}\text { Experienc } \\
\text { ed large } \\
\text { exporter }\end{array}$ & $\begin{array}{l}\text { Experienc } \\
\text { ed small } \\
\text { exporter }\end{array}$ & $\begin{array}{l}\text { The } \\
\text { experime } \\
\text { ntal } \\
\text { exporter }\end{array}$ & $\begin{array}{l}\text { The } \\
\text { exploring } \\
\text { firm }\end{array}$ \\
\hline
\end{tabular}

Table 2. the Quality Management and Internationalization information is summarized.

Strong commitment to quality was observed irrespective of fact that whether a formal quality management system was enforced or not. Nearly $80-90 \%$ of firms are ISO certified showing their belief to adopt ISO certification as a starting point. HRD factors are considered to be the crux of efforts for achieving TQM; which is in consonance with literature. Customer satisfaction, product design/quality and management commitment have been identified as the factors in which a firm must excel if it wants to proceed ahead 
with Internationalization. All these factors are in fact outcome of TQM; hence we can say that TQM practices enhance process of Internationalization.

All the companies feel that without emphasis on quality and TQM parameters, Internationalization cannot proceed ahead. However marketing efforts and personal contacts are considered to be other important parameter for internationalization. Large companies by virtue of maintaining some sort of systematic operations were not pressurized by the customers to adopt ISO standards. However medium \& small companies were to some extent required to adopt ISO standards by outside clients to enhance their credibility and commitment to quality. Increase in exports was experienced by nearly all companies as a result implementation of quality management system. Product design \& technology aspects improved, new machines were installed, laboratory results were sought for various incoming raw materials and as a result tighter conformance to customer's given specification was observed, causing increased customer satisfaction. Cost control and control of reject rate improved considerably as a result of quality management practices; causing increased profits. However in case where quality management was not being practices, the progress remained static. The different companies studied were found to be at different stage of internationalization organizations have older age of quality management programmes were found at advanced stage of internationalization.

These case studies confirm the findings regarding implementation of TQM and its impact on Internationalization as reported in literature like increase in exports. There exists a positive relationship between implementation of quality management and the factors indicating progress in the process of Internationalizations, which leads to the finding that quality management leads to enhanced Internationalization.

\section{Statistical Analysis}

Data obtained as result of survey show that $92 \%$ of respondents consider product quality as a competitive edge factor whereas $77.3 \%$ believe that quality of raw material is also a competitive edge factor. $95.3 \%$ respondents agree that exporting firms pay more attention to Quality/TQM and $90.6 \%$ perceive that firms practicing TQM are more likely to be an exporter. $87.2 \%$ think that exporting firms are more likely to seek ISO certification while $97.7 \%$ agree that exporting firms are involved in quality management programme in one way or the other. $90.6 \%$ say that firms practicing TQM has a positive impact on level of sales, and $89.4 \%$ believe that TQM increases level of exports. TQM increases foreign market share is believed by about $92.9 \%$ respondents. All in all, in quality related questions, the frequency obtained is around $90 \%$ (Abdi, 2005). This high frequency obtained speaks itself of the importance and positive role of quality management in the process of internationalization.

Question No.1 with 15 sub-questions was asked to determine different factors prompting the organizations to enter the international market and their relative importance as far as sports industry in Sialkot (Pakistan) is concerned. A ranking table in the shape of average weighted replies is shown in Table 3. A mean value nearer to 01 indicates higher importance of the factor. The third most important factor is "having unique quality product". This 
supports the present study and belief of the researcher. Quality Management makes possible maintaining unique quality and this in fact paves way for internationalization.

\begin{tabular}{|c|l|c|c|c|}
\hline $\begin{array}{c}\mathrm{S} \\
\#\end{array}$ & Question & $\mathrm{N}$ & Mean & Std. Deviation \\
\hline 15 & Receipts of orders from abroad & 71 & 1.21 & .74 \\
\hline 5 & Management interest in exports & 73 & 1.32 & .64 \\
\hline 10 & Having unique quality product & 71 & 1.37 & .80 \\
\hline 11 & Having extra growth potential by exports & 71 & 1.41 & .62 \\
\hline 9 & $\begin{array}{l}\text { Having exclusive information of foreign } \\
\text { markets }\end{array}$ & 72 & 1.64 & .83 \\
\hline 12 & Possibility of higher sale return from export & 73 & 1.64 & .84 \\
\hline 6 & Starting of exports by competitors & 72 & 1.69 & 1.04 \\
\hline 02 & To get large scale production benefits & 73 & 1.85 & 1.20 \\
\hline 03 & Having idle capacity and want to utilize it & 72 & 1.94 & 1.03 \\
\hline 08 & Having easy access to export finance & 72 & 2.17 & 1.11 \\
\hline 04 & Encouragement of External agents & 71 & 2.44 & 1.42 \\
\hline 13 & Govt. export related incentives & 72 & 2.47 & 1.34 \\
\hline 07 & Intense competition in Domestic Market & 71 & 2.55 & 1.43 \\
\hline 01 & High Level of unsold stock & 70 & 2.74 & 1.50 \\
\hline 14 & Lack of growth in domestic market share & 64 & 3.05 & 1.41 \\
\hline
\end{tabular}

Table 3. Average \& Ranking: Factors in Internationalization

Question No.2 was asked to assess firm's feeling about different factors as they believe to be their point of competitive advantage in internationalization process. There were 16 different factors which could be their strength or weakness in the process of internationalization. A mean value nearer to 01 represents higher importance of the factor. Results are as below.

\begin{tabular}{|l|l|c|c|c|}
\hline $\begin{array}{l}\mathrm{S} \\
\#\end{array}$ & Question & $\mathrm{N}$ & Mean & Std. Deviation \\
\hline 05 & Customer Satisfaction & 86 & 1.29 & .59 \\
\hline 01 & Product quality & 87 & 1.32 & .66 \\
\hline 03 & Customer Service & 88 & 1.45 & .73 \\
\hline 14 & Managerial Commitment & 87 & 1.56 & .74 \\
\hline 04 & Market Information & 88 & 1.60 & .92 \\
\hline 09 & Quality of Marketing & 86 & 1.66 & .92 \\
\hline 11 & Quality of Raw Material & 88 & 1.70 & .91 \\
\hline 16 & Brand recognition & 88 & 1.74 & 1.12 \\
\hline 12 & Production Innovation & 85 & 1.76 & .95 \\
\hline 02 & Price & 87 & 1.77 & .84 \\
\hline 13 & Technology adopted & 85 & 1.92 & 1.04 \\
\hline 15 & Workforce & 87 & 1.92 & .99 \\
\hline 10 & Financial Strength & 86 & 1.99 & .93 \\
\hline 08 & Foreign Middleman Network & 81 & 2.12 & .94 \\
\hline 06 & Terms of Credit & 80 & 2.40 & .79 \\
\hline 07 & Local Middleman Network & 64 & 2.86 & .97 \\
\hline
\end{tabular}

Table 4. Average \& Ranking: Competitive Edge Factors. 
The four top most variables identified as the competitive edge factors are

1. Customer Satisfaction

2. Product Quality

3. Customer Service

4. Managerial Commitment

All the above four variables can only be achieved through adoption of TQM practices and hence TQM is playing a vital role in internationalization.

Q.No.3. with 2 sub-questions was asked to find out characteristics of firms engaged in international business. The top most characteristic identified is "giving weightage to customer's suggestion and specification in product design \& development", which is again a quality management outcome. As per table below, the next ranking shows the hall mark of exporting firms which have emphasis on quality management programmes. The next four ranks are directed towards the importance of quality management programme in internationalization. Again a mean value nearer to 01 represents higher degree of agreement with the statement.

\begin{tabular}{|c|l|c|c|c|}
\hline S \# & Question & $\mathrm{N}$ & Mean & Std. Deviation \\
\hline 21 & $\begin{array}{l}\text { A firm that starts exporting, gives heavy weightage to customer's } \\
\text { suggestions and specifications in new production design and new } \\
\text { product development. }\end{array}$ & 85 & 1.28 & .45 \\
\hline 7 & Exporting firms are more likely to pay attention to quality/TQM. & 85 & 1.32 & .60 \\
\hline 20 & $\begin{array}{l}\text { A firm after starting exports gives more attention to customer } \\
\text { satisfaction. }\end{array}$ & 85 & 1.39 & .54 \\
\hline 10 & $\begin{array}{l}\text { Exporting firms are more likely to get involved in quality management } \\
\text { program. }\end{array}$ & 86 & 1.47 & .55 \\
\hline 11 & Firms practicing TQM give a consistent increase in exports. & 85 & 1.56 & .66 \\
\hline 13 & $\begin{array}{l}\text { Exporting firms pay high attention to the quality of incoming raw } \\
\text { material. }\end{array}$ & 85 & 1.58 & .84 \\
\hline 08 & Firms practicing TQM are more likely to export. & 85 & 1.59 & .79 \\
\hline 06 & Exporting firms have more and a broad base customers & 86 & 1.59 & .71 \\
\hline 09 & Exporting firms are more likely to seek ISO certification & 86 & 1.72 & 1.12 \\
\hline 17 & Exporting firms perform better in financial terms & 87 & 1.76 & .78 \\
\hline 18 & $\begin{array}{l}\text { Exporting firms give more attention to employee participation in } \\
\text { decision making. }\end{array}$ & 87 & 1.83 & .77 \\
\hline 14 & $\begin{array}{l}\text { Exporting firms are more likely to have a small number of defects in } \\
\text { production process }\end{array}$ & 85 & 1.84 & .77 \\
\hline 12 & Exporting firms have more ISO or quality certified suppliers & 84 & 1.94 & .97 \\
\hline 04 & Manufacturing firm will be more likely to be an exporter. & 85 & 1.98 & .95 \\
\hline 16 & $\begin{array}{l}\text { Exporting firms are more likely to have a specialized quality personnel } \\
\text { to maintain the quality of production }\end{array}$ & 87 & 2.02 & .94 \\
\hline 05 & Old age firms more likely to be an exporter. & 83 & 2.05 & 1.03 \\
\hline 19 & Exporting firms are more likely to give attention to employee training. & 87 & 2.06 & .99 \\
\hline 15 & $\begin{array}{l}\text { Exporting firms are more likely to have a very small number of } \\
\text { defective final products due to their quality programme }\end{array}$ & 84 & 2.13 & .98 \\
\hline 01 & New firms with large scale turnover are more likely to be exporter. & 86 & 2.43 & 1.02 \\
\hline 02 & New firms exporting their product will be more profitable. & 86 & 2.74 & .92 \\
\hline 03 & New firms with large employment size are more likely to be exporter. & 82 & 2.90 & 1.06 \\
\hline
\end{tabular}

Table 5. Characteristics of Exporting Firms 
To find out the results of quality management, question No.4 with 12 sub-questions was asked and following ranking table was generated based on responses. Again a mean value nearer to 1 depicts higher degree of improvement.

\begin{tabular}{|c|l|c|c|c|}
\hline $\begin{array}{l}\mathrm{S} \\
\#\end{array}$ & Question & $\mathrm{N}$ & Mean & Std. Deviation \\
\hline 08 & Customer Satisfaction & 84 & 1.27 & .45 \\
\hline 04 & Level of Exports & 85 & 1.38 & .67 \\
\hline 02 & Level of Sales & 86 & 1.40 & .58 \\
\hline 01 & Cost of Production & 85 & 1.41 & .70 \\
\hline 03 & Time of Production & 86 & 1.42 & .64 \\
\hline 12 & Overall Business Immage & 76 & 1.45 & .53 \\
\hline 09 & Staff Commitment & 85 & 1.52 & .50 \\
\hline 11 & Workers satisfaction & 85 & 1.54 & .55 \\
\hline 07 & Market Share (Exports) & 84 & 1.65 & .61 \\
\hline 05 & Profitability & 85 & 1.89 & .62 \\
\hline 10 & No. of defective products & 84 & 2.08 & 1.10 \\
\hline 06 & Market Share (Local) & 61 & 2.41 & .72 \\
\hline
\end{tabular}

Table 6. Average \& Ranking: Results of Quality Management.

The No.2 and 3 in the rank comes Export level and level of sales and the next one is cost of Production. Internationalization is gradual increase in foreign business. The rise in export level and the level in sales as a consequence of quality management speaks itself for role of quality management in the process of internationalization. Naturally with the increase of quality control, the product becomes more and more acceptable to foreign customers and hence the market improves and consequently the level of sales and level of exports.

\section{Discussion}

It has been observed in Data analysis that quality management has emerged as an important factor in the process of internationalization. ISO certification has also been found as an important step in the process of internationalization. Organizations now are converging towards standardization. As Strandsko (1985) described that multinational firms with international activities or multinational operations are continually changing and they are responding to the newly required standards which are being adopted by all kinds of business all over the world, so we can say that these international standards will force the organizations to adopt these standards and thus will help the companies in the international markets. Overall the internationalization process has been conceived as a "gradual process", taking place in incremental stages and over a relatively long period of time. So, it can be related with the fact that the $100 \%$ quality is also a gradual process and the companies try to achieve it with the passage of time. The companies in the short term can go for ISO 9000, which will pave the way for the adoption of total quality management in the long run.

As the "stages theory of internationalization" argues that firms proceed in a consistent stepwise fashion, so it can also be said that the firms move into the international markets in a gradual fashion by adopting the internationally required concepts and practices. Quality is the only way by which you can sustain your long term growth and survival. And to ensure 
that the company is producing quality products, many companies are getting ISO 9000 certification to ensure their international customers that they are focusing and producing the products of high quality. So, ISO 9000 can be used as a stage, according to stage theory of internationalization, by/for any company to enter into new markets and to compete in the international markets.

As Wind et al (1973) consider internationalization as a process in which companies adopt special orientation and policies as they move along the different successive stages. The final stage of "geocentric" can be related with the fact that companies perceive the whole world as a potential market, thus they have to adopt the internationally required policies and standards if they want to operate and compete successfully in the international markets. As the Uppsala School (1977) primarily consider internationalization from the perspective of increased export dependence in a growing number of markets, it can be related with that the export now a days is dependent upon the adoption of new business practices and new international standards required by the international customers. So, with the growing and emerging new markets, the companies have to depend on these new markets and have to adopt the standards and practices required by these international markets. As Cunnigham and Homse (1982) perceived that exporting occurs in a development stage in which organizations learn the different practices and concepts and accordingly respond to that, so it can be related with that companies have to respond to the external stimuli which induces a change in existing business practices and results in the adoption of newly required practices and standards. It has become imperative for the companies to respond effectively to these stimuli. Companies experience different practices in the international markets, which accumulates organizational learning over time. Therefore, the companies have to adjust and respond to foreign markets by fulfilling their requirements of quality management system.

As the international marketing behavior of firms is related to managerial aspirations and the level of commitment that management is willing to give to the international marketing effort, so similar is the case with motivation and commitment of management to adopt quality management system. Motivation can be proactive and reactive. As the many proactive and reactive factors influence the firms to adopt different practices in order to respond to environmental changes and adjust to them by changing their activities over time, same is case with motivations for pursuing quality management. The proactive motivations for quality management adoption can be profit consideration, managerial urge, desire for continuous growth and to retain market share etc. The reactive motivations for quality management can be competitive pressures, as a international trend and special requirements from international customers. Change agents for quality management can be internal and external. Internal change agents include professional management, new management and other significant internal change, while External change agents can be demand from customers, competition etc.

Therefore, overall we can see that link between internationalization and quality management exists and the companies can gain many benefits in the international market by having quality management system in place. It will not be overemphasized if we say that quality management system in a pre-requisite for internationalization. 


\section{Concluding remarks}

Results of this study suggest that the success or failure of TQM implementation in manufacturing sector of Pakistan depends mainly on management commitment to quality and top management's visible participation in TQM implementation activities. Findings also indicate that most of the owners and top management executives in this industry, despite of realizing the substantial benefits of using TQM practices, opt for limited use of some specialized quality management techniques like ISO, JIT or six sigma depending on the requirements of their export market. Whilst, analysis reveals that use of quality raw material, efficient processes, and achieving zero defect standard of quality are most critical factors for successful implementation of TQM practices in sports industry.

This study also guides us towards finding relevant functional domain of management like human resource, marketing, finance and other functional areas for assigning the responsibility to implement quality management practices in their functional domain and making efforts for creating synergy among all functional areas of the business. This way, the firms in the selected industries of manufacturing sector of Pakistan may be able to establish integrated system for successful implementation of TQM practices.

Results of this study conclude that the industries rise to higher stage of internationalization as they grow in size and age of quality management. ISO certification, though not essential for internationalization, serves as a stepping stone in the process. The industry is aware that internationalization cannot be increased unless strong commitment to quality is maintained. Throughout the survey results quality management has been identified as one of top most important factors in internationalization. Quality Management increases level of exports and sales \& hence increases level of exports and sales \& hence increases business. Exporting firms place quality management very high on their ladder of importance of exporting factors. Quality Management reduces production cost and reject rate.

\section{References}

Abdi, S.N.A. (2005); Ph.D Thesis submitted to B.Z. University, Multan (Pakistan)

Abdullah, M. M. B., B. M. Shah, et al. (2008). "The Importance of Soft Factors for Quality Improvement: Case study of Electrical \& Electronics Firms in Malaysia." International Journal Of Business Management 3(12): 60-69.

Adam, E.E. (1994). Alternative quality improvement practices and Organizational performance. Journal of Operations Management, 12(1): 27-44.

Adam, E.E., Corbett, L.M., Flores, B.E., Harison, N.J., Lee, T.S., Rho, B.H., Ribera, J., Samson, D., and Westbrook, R. (1997). An international study of quality improvement approaches and firm's performance. International Journal of Operations and Production Management, 17(9): 842-873.

Ahire, S.L., Golher, D.Y. and Waller, M.A. (1996). Development and validation of TQM implementation constructs. Decision Science, 27(1): 23-56.

Al-Nofal, A., Zairi, M. and Ahmed, A.M. (May, 2004). Critical factors of TQM: An international comparative benchmarking analysis. Paper presented at the National Conference on Quality, Tripoli, Libya. 
Anderson, J.C., Rungtusanatham, M. and Schroeder, R.G. (1994). A theory of quality management underlying the Deming management method. Academy of Management Review, 19(3): 472-509.

Anderson, J.C., Rungtusanatham, M., Schroeder, R.G. and Deveraj, S. (1995). A path analytical model of a theory of quality management underlying the Deming management method; preliminary empirical findings. Decision Sciences, 26(5): 63758.

Australian Manufacturing Council (1994). Leading the Way: A Study of Best Manufacturing Practices in Australia and New Zealand (2nd ed). Melbourne Australian Manufacturing Council

Awan, H.M. (2003) "An Evaluation of ISO 9000 Registration Practices in the Sports Goods Industry of Pakistan" Journal of Managerial Finance, Vol. 29, PP 109-134

Bello, D.C. and Barksdale, H.C. (1986), "Exporting at Industrial Trade Shows", Industrial Marketing Management, Vol. 15, PP. 197-206.

Bertram, D. (1991). "Getting started in total quality management." TOTAL QUALITY MANAGEMENT 2(3): 79-82.

Berry ,H.T .(1998) "Managing the Total Quality Transformation” McGraw Hill New York, NY.

Bilkey W.J. and Tesar G (1977) “ The Export Behaviour of Smaller Size Wisconsin Manufacturing Firms". Journal of International Business Studies PP 93-6.

Bilkey, W.J. (1978), "An Attempted Integration of the Literature on the Export Behaviour of Firms", Journal of International Business Studies, No. 9,. PP. 33-46

Cavusgil, S.T. Bilkey, W.J. and Tesar, G., (1979) "A Note on the Export Behaviour of Firms: Exporter Profiles", Journal of Inernational Business Studies, Vol. 10, Spring/Summr, PP 61-77.

Black, S.A. and Porter, L.J. (1996). Identification of the critical factors of TQM. Decision Sciences, 27(1): 1-27.

Baidoun, S. (2003). An empirical study of critical factors of TQM in Palestinian organizations. Logistics Information Management, 16(2): 156-171.

Bauerschmidt, A., Sullivan, D. and Gillespie, K. (1985), “Common Factors Underlying Barriers to Export: Studies in the US Paper Industry", Journal of International Business studies, Fall, PP.111-23.

Cavusgil S.T. and Nein, J.R. (1981) “Internal Determinants of Export Marketing Behaviour: An Empirical Investigation", Journal of Marketing Research, Vol. 18, February, PP.114-9.

Cavusgil S.T., (1984) “Organizational Characteristics Associated with Export Activity, Journal of Management Studies, Vol. 21, No.1, PP 3-22.

Cavusgil, S.T. (1980), "On the Internationalization Process of Firms", European Research, No. 8, November, PP. 273-81.

Christensen, C.H., da Rfocha, A and Gertner, R.K. (1987), “An Empirical Investigation of the Factors Influencing Exporting Success of Brazilian Firms", Journal of Business Studies, Fall, PP. 61-77.

Cobb, C. G. (2003). From Quality to Business Excellence: A Systems Approach to Management. Wisconsin, ASQ Quality Press, Milwaukee.

Cooper, R.G. and Kleinschmidt, E.J. (1985) “The Impact of Export Strategy on Export Sales Performance", Journal of Inernational Business Studies, Spring, PP 37-55. 
Cunningham and Homse (1982) An Interaction Approach to Marketing Strategy" in International Marketing and Purchasing of Industrial Goods: An Iteration Approach, Edited by H.Hansson, Chhichester, John Wiley 328-345.

Czinkota, M.R, 1982, Export Development Strategies, US Promotion Policies, New York, Praeger Pubications.

Dale, B.G. (1994), "A Generic Framework For Managing Quality Improvement: Theory And Practice", Quality Management Journal, July, pp. 11-29.

Day George S. (1994): "The capabilities of market-driven organizations". Journal of Marketing, Vol. 58, Issue 4, pp. 37-51.

Deming, W. E. (1986). Out of the Crisis. MIT Centre for Advanced Engineering Study. MA, Cambridge.

Deshpande Rohit, Farley John U., Webster Frederick (1993): “Corporate culture, customer orientation, and innovativeness." Journal of Marketing. Vol. 57 (January 1993), pp. 23-37.

Diamantopoulos, A and Inglis, K. (1988), "Identifying Differences Between High and Low Involvement Exporters", International Marketing Review, Vol. 5, Summer PP. 5260.

Eid, R. (2009). "Factors affecting the success of world class manufacturing implementation in less developed countries: The case of Egypt." Journal of Manufacturing Technology Management 20(7): 989-1008.

Easton, G. S. (1993). "The 1991 state of US total quality management: a Baldrige examiner's perspective." California Management Review 35(3): 32-54.

EFQM (2003). EFQM Introducing Excellence. Brussels.

Frooman, J. (1999) Stakeholder influence strategies. Academy of Management Review 24(2), 191-205.

Firat, A.F and Dholakia, N (2006), "Theoretical and philosophical implications of Postmodern debates; some challenges to modern marketing." Marketing Theory, Vol. 6 No.2 pp. 123-162

Garvin, D. A. (1993). "Building a learning organization." Harvard Business Review 71(4): 7891.

Gronhaug, K. and Lorenzen, T. (1982), "Exploring Industrial Export Strategies" , in An Assessment of Marketing Thought and Practice, American Marketing Association Proceedings, Vol. 48, PP. 294.8.

H Awan, I Bhatti, A Qureshi, S Bukhari (2009) "Critical total quality management factors and financial performance of the firm," International Journal "Total Quality Management \& Excellence", Vol. 37, No. 3, 2009

Hunt, S.D. and Morgan, R.M. (1995). "The comparative advantage theory of competition." Journal of Marketing, 59 (April), 1-15.

Irani, Z., A. Beskese, et al. (2003). "Total quality management and corporate culture: constructs of organisational excellence." Technovation 23.

Jamshed, H.K. (2003). Impact of Total Quality management on Productivity The TQM Magazine 15(6): 374-380.

Jaworski, Bernard J., Kohli Ajay K. (1993): Market orientation: Antecedents and consequences. Journal of Marketing. Vol. 57, Issue 3, 1993, pp. 53-71.

Johanson, J. and Wiedersheim-Paul, F. (1975), “The Internationalization of the Firm - Four Swedish Cases", Journal of Management Studies, Vol. 12, PP. 305-22. 
Johanson J and Vahlne J.E (1977) “The Internationalization Process of the Firm - A model of Knowledge Development and increasing foreign market commitment", Journal of International Business Studies' Vol. 8, No.1, Spring/Summer PP.222-23

J. W. Armitage, N. A. B. M. C. C. (2003). The 7 essentials of business excellnce. t. t. w. solutions: $1-27$.

Joynt P (1982) "An Empirical Study of Nowegian Export Behaviour" in Czinkota M.R and Tesar G. (Eds). Export Management: An International Context PP 55-69.

Juran, J. M. (1993). "Made in USA: a renaissance in quality." Harvard Business Review 71(4): 42-50.

Kanji GK and H. Yui (1997). "Total Quality Culture". Total Quality Management, 8(6), 4 17-428

Karim, M. A., A. J. R. Smith, et al. (2008). "A Comparative study of manufacturing practices and perfomance variables." International Journal of Production Economics 112(841859).

Kohli Ajay K, Jaworski Bernard J.( 1990), "Market Orientation: The construct, research propositions, and managerial implications." Journal of Marketing, Vol. 54, Issue 2, , pp. 1-18.

Karuppusami, G. and R. Gandhinathan (2006). Pareto analysis of critical success factors of total quality management: a literature review and analysis. The TQM Magazine, 18 (4): 372-85.

Kaynak E \& Kothari V (1984), “Export behaviour of small and medium sized manufacturers: Some policy guidelines for international marketers". Management International Review; Vol. 24; No.2, PP-61-9

Kirpalani V.H. and Machintosh N.B. (1980) "International Marketing Effectiveness of Technology Oriented Small Firms", Journal of International Business Studies, Winter PP. 81-90.

Lau, C. A. and M. A. Idris (2000). The Sofrt foundation of Critical success factors on TQM: Implementation in Malaysia. Regional Symposium on Qulaity and Automation, Pennang.

Lee, T.Y., Leung, H.K.N. and Chan K.C.C. (1999) “Improving quality management on the basis of ISO 9000" The TQM Magazine, Vol. 11 No.2, pp. 88-94

Lipovatz, D., Stenos, F. And Vake, A. (1999) “Implementation of ISO 9000 quality system in Greek enterprises", International Journal of Quality \& Reliability Management, Vol. 16 No.6, pp. 534-551.

Macedo-Soares, T. D. L. v. A. d. and a. D. C. Lucas (1996). "Key quality management practices of leading firms in Brazil: findings of a pilot-study." The TQM Magazine 8(4): 55-70.

Martinez, R. and Rodriguez, J.F. (1997), “Quality service model oriented towards customer" , Computer Ind. Engineering, Vol.33, No.1-2. Pp. 153-156

Marrewijk, T. W. H. a. M. v. (2001). "The Social Dimensions of Business Excellence." Corporate Environmental Strategy 8(3): 223-233.

McGuinness, N.W. and Little B. (1981), "The Influence of Product Characteristics on the Export Performance of New Industrial Products", Journal of Marketing Spring, PP. 110-22.

Mohr-Jackson, I. (1991), "Broadening the market orientation; an added focus on internal customer", Human resource Management Journal Vol. 30 (winter), pp. 455-67 
Mora-Monge, C. A., Gonz ' lez, M.E., Quesada, G. and Rao, S.S. (2008). "A study of AMT in North America: a comparison between developed and developing countries." Journal of Manufacturing Technology Management 19(7): 812-29.

Manz, C. C. and H. P. Sims (1993). Business without Bosses. NY, John Wiley, New York.

Najeh, R. I. and Kara-Zaitri, C. (2007). A Comparative Study of Critical Quality Factors in Malaysia, Palestine, Saudi Arabia, Kuwait and Libya. Total Quality Management $\mathcal{E}$ Business Excellence,18(1): 189 -200.

Narver John C., Slater Stanley F. (1990) "The effect of a market orientation on business profitability." Journal of Marketing, Vol. 54 Issue 4, , pp. 20-36.

Nils Erik Aaby \& Stanley F. Slater. (1989) "Management Influences on Export Performance: A Review of the Empirical Literature 1978-88. International Management Review, Vol. 6, No.4.

Noreeha Husain, M. A., Fazali Idrees \& Ridzuan Muhammad Saghir (2001). "The Malaysian Total Performance Excellence Model: A conceptual framework." TOTAL QUALITY MANAGEMENT 12(7\&8): 926-931.

Quazi, H.A. and Padibjo, S.R. (1997) “A journey towards total quality management through ISO 9000 certification - a Singapore experience", The TQM Magazine, Vol. 9. Number 5, pp. 364-371.

Ramirez, C. and Loney, T. (1993, January). Baldrige Award Winners identify the essential activities of a successful quality process. Quality Digest Magazine, pp.38-40.

Reid S.D. (1982), "The impact of size on export behaviour in small firms", in Czinkota M.R and Tesar G (Eds), Export Management: An international context; Preager Publishers, New York PP 18-38.

Rosson, P.J. and Ford. L.D. (1982), “Manufacturer-Overseas Distributor Relations and Export Performance", Journal of International Business Studies, Fa.. PP. 57-72.

Saraph, J.V., Benson, P.G. and Schroeder, R.G. (1989). An instrument for measuring critical factors of quality management. Decision Sciences, 20(4): 457-78.

Schlosser, Francine K. and Mcnaughton, Rod B. (2007) 'Internal stakeholder views of a market orientation strategy: implications for implementation', Journal of Strategic Marketing, 15:4, 307 - 325

Seghezzi, H. D. (2001). "Business Excellence: What is to be done?" TOTAL QUALITY MANAGEMENT 12(7\&8): 861-866.

Sila, I. and Ebrahimpour, M. (2005). Critical Linkages among TQM factors and Business Results. International Journal of Operations and Production Management, 25(11): 11231155.

Silva, J. G. D., O. Tadashi, et al. (2005). "Looking through and Beyond the TQM Horizon lessons learned from world class companies." The TQM Magazine 17(1): 67-84.

Siropolis N (1994) "Small Business Management: A guide to Entrepreneurship" Boston: Houghton Mifflin.

Smith, S. (1994). The Quality Revolution. Didcot, Management Books 2000 Ltd.

Teece, D. J., Pisano, G., \& Shuen, A. (1997). “Dynamic capabilities and strategic management," Strategic Management Journal, 18 (August), 509-534.

Strandsko J (1985) “Towards a new Approach for Studying Internationalization Process of Firms", Annual Conference of International Business Association, Glasgow, Scotland 
Thiagarajan, T. and Zairi, M. (1997). A review of total quality management in practice: understanding the fundamentals through examples of best practice applications Part I. The TQM Magazine, 9(4): 270-286.

Thiagarajan, T. and Zairi, M. (1998). An empirical analysis of critical factors of TQM; a proposed tool for self assessment and benchmarking purpose. Benchmarking for Quality Management \& Technology, 5(4): 291-303.

Thiagrajan, T. and M. Zairi (1997). "A review of total quality management in practice: understanding the fundamentals through examples of best practice applications Part I." The TQM Magazine 9(4): 270-286.

Tsiotras, G. And Gotzamani, K. (1998) “ ISO 9000 as an entry key to TQM: the case of Greek industry", International Journal of Quality and Reliability Management, Vol. 13 No.4, pp.64-76.

Tummala, V.M.R. and Tang, C.L. (1998) “Strategic quality management, Malcom Baldridge and European Quality Awards ISO 9000 certification - core concepts and comparative analysis" International Journal of Quality and Reliability Management, Vol. 13 No.4, pp.8-38.

Welch L.S \& Luostarinen R. (1988) "Internationalization: Evolution of a Concept", Journal of General Management Vol. 14. No.2, Winter PP 34-55.

Willson, D.D. and Collier, D.A. (2000). An empirical investigation of the MBNQA casual Model. Decision Sciences, 31(2): 361-90.

Wind Y, Douglas S.P. and Parmutter H.V. (1993) Guide Lines for Developing International Marketing Strategies", Journal of Marketing, 37 (April) pp 14-24.

Zairi, M. and Youssef, M.A. (1995). Benchmarking Critical Factors for TQM; Part I: Theory and Foundations. Benchmarking for Quality Management and Technology. 2(1): 5-20.

Youssef, M.A. and Zairi, M. (1995). Benchmarking Critical Factors for TQM; Part -II empirical results from different regions in the world. Benchmarking for Quality Management and Technology, 2(2): 3-19.

Youssef, M. A. (1995). "The impact of TQM on firms' responsiveness: an empirical study." Total Quality Management Journal. 


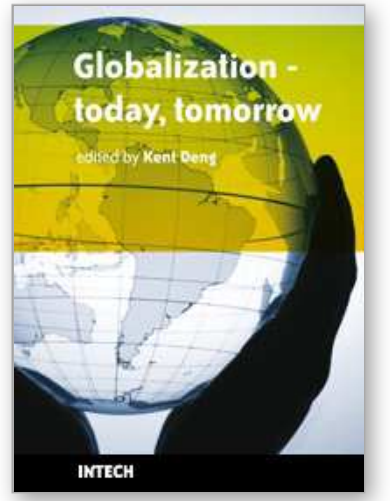

\author{
Globalization - Today, Tomorrow \\ Edited by Kent Deng
}

ISBN 978-953-307-192-3

Hard cover, 160 pages

Publisher Sciyo

Published online 05, October, 2010

Published in print edition October, 2010

This is a collective volume on present-day globalisation with nine chapters from authors of several academic disciplines. It covers wide aspects, ranging from the nature, impact, challenges and implications of globalisation to responses from a country or community when facing globalisation today or tomorrow. Policy suggestions are also made. This book will hence help the reader to understand the currently debated issues.

\title{
How to reference
}

In order to correctly reference this scholarly work, feel free to copy and paste the following:

M.Ishaq Bhatti, Hayat Muhammad Awan and Khuram Shahzad Bukhari (2010). Globalization and Firm's Quality Orientation: a Review of Total Quality Management Practices in Manufacturing Sector, Globalization Today, Tomorrow, Kent Deng (Ed.), ISBN: 978-953-307-192-3, InTech, Available from: http://www.intechopen.com/books/globalization--today--tomorrow/globalization-and-firm-s-quality-orientation-areview-of-total-quality-management-practices-in-manuf

\section{INTECH}

open science | open minds

\author{
InTech Europe \\ University Campus STeP Ri \\ Slavka Krautzeka 83/A \\ 51000 Rijeka, Croatia \\ Phone: +385 (51) 770447 \\ Fax: +385 (51) 686166 \\ www.intechopen.com
}

\author{
InTech China \\ Unit 405, Office Block, Hotel Equatorial Shanghai \\ No.65, Yan An Road (West), Shanghai, 200040, China \\ 中国上海市延安西路65号上海国际贵都大饭店办公楼 405 单元 \\ Phone: +86-21-62489820 \\ Fax: $+86-21-62489821$
}


(C) 2010 The Author(s). Licensee IntechOpen. This chapter is distributed under the terms of the Creative Commons Attribution-NonCommercialShareAlike-3.0 License, which permits use, distribution and reproduction for non-commercial purposes, provided the original is properly cited and derivative works building on this content are distributed under the same license. 